\title{
t(17;19) in Children with Acute Lymphocytic Leukemia: A Report of 3 Cases and a Review of the Literature
}

\author{
Katherine A. Minson, ${ }^{1}$ Pinki Prasad, ${ }^{1,2}$ Susan Vear, ${ }^{1,2}$ Scott Borinstein,, ${ }^{1,2}$ Richard Ho, ${ }^{1,2}$ \\ Jennifer Domm, ${ }^{1,2}$ and Haydar Frangoul ${ }^{1,2}$ \\ ${ }^{1}$ Department of Pediatrics, Monroe Carell Jr. Children's Hospital at Vanderbilt, Nashville, TN 37232, USA \\ ${ }^{2}$ Division of Pediatric Hematology/Oncology, Monroe Carell Jr. Children's Hospital at Vanderbilt, Nashville, TN 37232, USA
}

Correspondence should be addressed to Haydar Frangoul, haydar.frangoul@vanderbilt.edu

Received 19 November 2012; Accepted 12 December 2012

Academic Editors: D. J. Allsup, E. Arellano-Rodrigo, S. Langabeer, and P. Tsirigotis

Copyright (C) 2013 Katherine A. Minson et al. This is an open access article distributed under the Creative Commons Attribution License, which permits unrestricted use, distribution, and reproduction in any medium, provided the original work is properly cited.

Several cytogenetic abnormalities identified in patients with childhood acute lymphocytic leukemia (ALL) have been associated with a poor prognosis. There are several case reports in the literature describing $t(17 ; 19)$ in children with ALL. This translocation has been associated with hypercalcemia, coagulopathy, and poor outcome. We present three cases of ALL with t(17;19) treated at our institution and review the outcome of children reported in the medical literature.

\section{Introduction}

Over the past 2 decades, the outcome of children with acute lymphocytic leukemia has exceeded $80 \%$ in patients treated in developed countries [1]. Cytogenetic abnormalities, identified in fifty percent of all ALL patients, have long been identified as factors that can influence the risk of relapse. Some of the identified high risk cytogenetic abnormalities include hypodiploidy, $\mathrm{t}(4 ; 11)$, and $\mathrm{t}(9 ; 22)(\mathrm{q} 34 ; \mathrm{q} 11.2)[1,2]$. In current treatment protocols, patients with high risk features are stratified to a more intensive therapy and/or an allogeneic stem cell transplant.

The chromosomal rearrangement $t(17 ; 19)$, observed in less than $1 \%$ of precursor B ALL, has been identified as a poor prognostic indicator. This translocation, which juxtaposes the E2A and HLF genes, results in the creation of a mutant fusion protein that is thought to play a role in pathogenesis. Furthermore, this translocation results in the disruption of the $E 2 A$ gene which plays an important role in lymphopoiesis $[3,4]$. ALL with $t(17 ; 19)$ have been associated with hypercalcemia and coagulopathy, although the mechanism of these findings is unclear $[5,6]$. We report on 3 children with $t(17 ; 19)$ ALL and review the outcome of children with this translocation reported in the medical literature.

\section{Case Report}

Case 1. A 3-year-old female presented with progressive leg pain. Radiographic evaluation revealed multiple lytic lesions in the lower extremities and pelvis. Laboratory evaluation revealed hemoglobin of $8.6 \mathrm{~g} / \mathrm{dL}, \mathrm{WBC}$ count of $8,400 / \mu \mathrm{L}$, and platelet count of $162,000 / \mu \mathrm{L}$. She had hypercalcemia with serum calcium of $16.8 \mathrm{mg} / \mathrm{dL}$ (normal 8.5-10.5) and parathyroid hormone-related protein $(\mathrm{PTHrP})$ of $0.62 \mathrm{pmol} / \mathrm{L}$ (reference $<1.6)$. Bone marrow evaluation revealed pre-B ALL with $\mathrm{t}(17 ; 19)(\mathrm{q} 22 ; \mathrm{p} 13)$ in 15 of 20 metaphases. She received 3 -drug induction chemotherapy with dexamethasone $\left(6 \mathrm{mg} / \mathrm{m}^{2} /\right.$ day for 28 days), vincristine $\left(1.5 \mathrm{mg} / \mathrm{m}^{2}\right.$ weekly for 4 weekly doses), and peg asparaginase $\left(2500 \mathrm{IU} / \mathrm{m}^{2} /\right.$ dose on day $3)$. She received augmented consolidation therapy with cyclophosphamide $\left(1000 \mathrm{mg} / \mathrm{m}^{2} /\right.$ dose on day 1$)$, cytarabine $\left(75 \mathrm{mg} / \mathrm{m}^{2} /\right.$ dose daily for 4 days, days $1-4$, and days $8-11)$, vincristine $\left(1.5 \mathrm{mg} / \mathrm{m}^{2} /\right.$ dose on days 15 and 22$)$, mercaptopurine $\left(60 \mathrm{mg} / \mathrm{m}^{2} /\right.$ day days $\left.1-14\right)$, and peg asparaginase $\left(2500 \mathrm{IU} / \mathrm{m}^{2} /\right.$ dose on day 15$)$. However, three months after diagnosis she experienced bone marrow relapse. Re induction therapy was started with doxorubicine $\left(60 \mathrm{mg} / \mathrm{m}^{2}\right.$ on day 1$)$, vincristine $\left(1.5 \mathrm{mg} / \mathrm{m}^{2}\right.$ weekly for 4 doses), 
TABLE 1: Reported cases of $\mathrm{t}(17 ; 19)$ in childhood acute lymphoblastic lymphoma.

\begin{tabular}{|c|c|c|c|c|}
\hline Reference & Age (y)/Sex & DIC & Hypercalcemia & Outcome \\
\hline \multirow{2}{*}[13]{} & $16 / \mathrm{M}$ & Yes & Yes & Achieved remission, deceased \\
\hline & $15 / \mathrm{F}$ & Yes & At relapse & Deceased from relapsed disease \\
\hline [12] & $17 / \mathrm{F}$ & NA & $\mathrm{NA}$ & Deceased at $2 \mathrm{mo}$ \\
\hline \multirow{3}{*}{ [8] } & $17 / \mathrm{F}$ & No & No & BMT in 1st CR, deceased from relapsed disease \\
\hline & $11 / \mathrm{M}$ & No & Yes & Deceased from relapsed disease \\
\hline & $13 / \mathrm{M}$ & No & At relapse & BMT at relapse, remitted then deceased from relapsed disease \\
\hline \multirow{2}{*}[4]{} & $\mathrm{N} / \mathrm{A}$ & No & $\mathrm{N} / \mathrm{A}$ & Deceased from leukemia \\
\hline & $\mathrm{N} / \mathrm{A}$ & No & N/A & Deceased from leukemia \\
\hline [7] & $12 / \mathrm{F}$ & Yes & NA & Deceased from relapsed disease \\
\hline \multirow{3}{*}{ [6] } & $5 / \mathrm{F}$ & At relapse & At relapse & Deceased from relapsed disease \\
\hline & $5 / \mathrm{F}$ & Yes & No & Deceased from relapsed disease \\
\hline & $14 / \mathrm{M}$ & Yes & No & Alive on therapy at $12 \mathrm{~m}$ \\
\hline [11] & $14 / \mathrm{F}$ & No & At relapse & Deceased from relapsed disease \\
\hline [14] & $14 / \mathrm{F}$ & No & Yes & BMT at relapse, deceased from infection after-transplant \\
\hline \multirow{3}{*}{ [5] } & $10 / \mathrm{M}$ & At relapse & At relapse & Deceased from relapsed disease \\
\hline & $4 / \mathrm{M}$ & No & Yes & Deceased from relapsed disease \\
\hline & $12 / \mathrm{F}$ & At relapse & At relapse & Deceased from relapsed disease \\
\hline [9] & $10 / \mathrm{M}$ & No & No & Deceased from relapsed disease \\
\hline
\end{tabular}

prednisone ( $60 \mathrm{mg} / \mathrm{m}^{2} /$ day for 28 days), and peg asparaginase $\left(2500 \mathrm{IU} / \mathrm{m}^{2} /\right.$ dose weekly for 4 doses staring day 3$)$. Following this salvage therapy bone marrow showed persistent disease. She went to receive dexamethasone $\left(10 \mathrm{mg} / \mathrm{m}^{2} /\right.$ day, days $1-5)$, vincristine $\left(1.5 \mathrm{mg} / \mathrm{m}^{2} /\right.$ dose weekly for 2 doses, days 1 and 8$)$, peg asparaginase $\left(2500 \mathrm{IU} / \mathrm{m}^{2} /\right.$ dose on day 8$)$, methotrexate $\left(1000 \mathrm{mg} / \mathrm{m}^{2}\right.$ infused over 36 hours staring on day 1$)$, thioguanine $\left(100 \mathrm{mg} / \mathrm{m}^{2} /\right.$ day, days $\left.1-5\right)$, and cytarabine $\left(100 \mathrm{mg} / \mathrm{m}^{2} /\right.$ day for 3 days as continuous infusion days 3-6). Following this therapy, the bone marrow continued to show persistent disease. Final re induction attempt was with clofarabine $\left(52 \mathrm{mg} / \mathrm{m}^{2} /\right.$ day for 5 days) but she failed to respond with bone marrow evaluation showing $87 \%$ blats. The patient died 13 months after her diagnosis with persistent disease.

Case 2. A 14-year-old female presented with bone pain, weight loss, bruising, and epistaxis. Her initial blood count demonstrated a platelet count of $35,000 / \mu \mathrm{L}$, hemoglobin of $5.0 \mathrm{~g} / \mathrm{dL}$, and WBC of $13,600 / \mu \mathrm{L}$ with $80 \%$ circulating blasts. Other laboratory data included normal calcium and a prolonged INR of 1.9 with low fibrinogen of $76 \mathrm{mg} / \mathrm{dL}$. Cytogenetic evaluation of the bone marrow revealed pre-B ALL with $\mathrm{t}(17 ; 19)(\mathrm{q} 22$;p13) in all 20 metaphases, with Trisomy 4 and 22 . She received 4 -drug induction chemotherapy with prednisone $\left(60 \mathrm{mg} / \mathrm{m}^{2} /\right.$ day for 28 days), daunorubicin (25 mg/m²/day weekly for 4 doses starting day 1 ), vincristine ( $1.5 \mathrm{mg} / \mathrm{m}^{2}$ weekly for 4 weekly doses), and peg asparaginase (2500 IU/m $/ \mathrm{m}^{2} /$ dose on day 3 ). Postinduction bone marrow evaluation revealed morphologic remission but $0.4 \%$ blasts by flow cytometry. She received augmented consolidation chemotherapy with cyclophosphamide, cytarabine, vincristine, mercaptopurine, and peg asparaginase identical to Case 1. After consolidation she received interim maintenance with high dose methotrexate $\left(5000 \mathrm{mg} / \mathrm{m}^{2} /\right.$ dose on days 1 and 15). She subsequently underwent an allogeneic bone marrow transplant from an HLA identical sibling. She received a preparative regimen with total body irradiation (1320 cGy divided in 8 fractions over 4 days) followed by cyclophosphamide $(60 \mathrm{mg} / \mathrm{kg} /$ dose for 2 days). She received a bone marrow graft with a total nucleated cell dose of $3.02 \times$ $10^{8} / \mathrm{kg}$ and a total CD $34+$ cell dose of $5.5 \times 10^{6} / \mathrm{kg}$. Graft versus host disease (GVHD) prophylaxis was with cyclosporine and methotrexate $\left(15 \mathrm{mg} / \mathrm{m}^{2}\right.$ on day +1 and $10 \mathrm{mg} / \mathrm{m}^{2}$ on days +3 , +6 and +11$)$. She did not have any GVHD and she was tapered off immune suppression by 5 months after transplant. Eight months after transplant, she experienced bone marrow and extramedullary relapse (skin lesion). She received reinduction chemotherapy with doxorubicine $\left(60 \mathrm{mg} / \mathrm{m}^{2}\right.$ on day 1$)$, vincristine $\left(1.5 \mathrm{mg} / \mathrm{m}^{2}\right.$ weekly for 4 doses), prednisone $\left(60 \mathrm{mg} / \mathrm{m}^{2} /\right.$ day for 28 days) and peg asparaginase (2500 iu/m²/dose weekly for 4 doses) but she died of disseminated fungal infection 10 months after transplant.

Case 3. A 16-year-old male presented with a 2-week history of bone pain and low grade fever. Radiographic evaluation of his lower extremities showed multiple lytic lesions. Laboratory evaluation revealed hemoglobin of $10.4 \mathrm{~g} / \mathrm{dL}$, WBC count of $6,000 / \mu \mathrm{L}$, platelet count of $112,000 / \mu \mathrm{L}$, 
calcium of $15.6 \mathrm{mg} / \mathrm{dL}, \mathrm{PTHrP}$ of $<1.1 \mathrm{pmol} / \mathrm{L}$ (reference $0-4$ ), and creatinine of $3.75 \mathrm{mg} / \mathrm{dL}$ (normal $<1.2$ ). Bone marrow evaluation revealed pre-B ALL $t(17 ; 19)(q 22 ; p 13)$ in all 20 metaphases. He received 4-drug induction chemotherapy with prednisone, daunorubicin, vincristine, and peg asparaginase. Bone marrow at the end of induction evaluation revealed $1.5 \%$ residual leukemia by flow cytometry. He received augmented consolidation chemotherapy (similar to Case 1) but his bone marrow at the end of consolidation therapy demonstrated $1.6 \%$ persistent leukemia blasts by flow. He underwent re-induction chemotherapy with cyclophosphamide ( $400 \mathrm{mg} / \mathrm{m}^{2} /$ day for 5 days), etoposide (100 mg/m $/ \mathrm{m}^{2}$ day for 5 days), and clofarabine $\left(40 \mathrm{mg} / \mathrm{m}^{2} /\right.$ day for 5 days). Three weeks following this re-induction therapy he died of disseminated fungal infection.

\section{Discussion}

The chromosomal rearrangement $t(17: 19)$ in childhood ALL is rare but is increasingly recognized as a clinically significant cytogenetic abnormality. We report three cases to contribute to the growing body of the literature about this translocation and the associated clinical features [4].

Eighteen cases of $t(17 ; 19)$ associated ALL had been previously reported in the English literature (Table 1) [414]. There are a number of common clinical features, which are demonstrated in these cases. Some of the first described cases presented with disseminated intravascular coagulation (DIC), a rare finding in childhood ALL [13]. Of the 17 cases with available data, 8 had evidence of DIC either at diagnosis or at relapse. Case 2 reported here presented with a prolonged PTT and hypofibrinogenemia consistent with DIC.

Another clinical feature commonly seen with $\mathrm{t}(17 ; 19)$ ALL is hypercalcemia. This was demonstrated in ten of thirteen previously reported cases with available data. Two of the three cases reported here (Cases 1 and 3) were associated with significant hypercalcemia. It has been suggested based upon previous cases that hypercalcemia in $t(17 ; 19)$ patients is partly parathyroid hormone-related protein (PTHrP) mediated [5]. However, this association was not observed in our patients as both had normal levels of PTHrP.

Perhaps most notably, this translocation has been thought to be a poor prognostic indicator with patients having poor response to initial therapy and early relapse. Of the twentyone reported cases, all patients have died of progressive disease with the exception of one who was alive on therapy at 1-year after diagnosis with no long-term follow-up data [6]. Two cases presented here were rapidly progressive with poor response to standard therapy leading to early relapse in Case 1 and failure to achieve remission in Case 3. Case 2 underwent allogeneic bone marrow transplant in first complete remission but still went on to relapse 8 months after transplant. There is one previously reported case of a patient undergoing stem cell transplant in first complete remission with eventual relapse and death [8]. It should be noted that both patients died after relapse and not from complications of transplant. Recently Glover et al. reported on in vitro sensitivity of leukemia blasts from a patient with $t(17 ; 19)$ to dasatinib a tyrosine kinase inhibitor [9]. The patient had a transient clinical response to combination of dasatinib and chemotherapy although he eventually relapsed and died during the re-induction therapy.

The cases reported here are consistent with previous evidence linking $\mathrm{t}(17 ; 19)$ ALL with DIC, hypercalcemia, and a poor prognosis. In the current Children's Oncology Group studies, these patients are not classified as very high risk. Based upon previous cases and our experience, we conclude that $t(17 ; 19)$ in ALL should be considered a very highrisk indicator and treated as such. Novel and more aggressive therapies including tyrosine kinase inhibitors, targeted immune therapies, and allogeneic stem cell transplant should be considered in these patients.

\section{Acknowledgment}

We would like to thank Alisha McCord for the administrative support.This project was supported by the Carolyn Perot Rathjen Chair in Pediatrics, Nashville, TN, USA, $(\mathrm{H}$. Frangoul).

\section{References}

[1] C. H. Pui, L. L. Robison, and A. T. Look, "Acute lymphoblastic leukaemia," The Lancet, vol. 371, no. 9617, pp. 1030-1043, 2008.

[2] C. H. Pui, W. L. Carroll, S. Meshinchi, and R. J. Arceci, "Biology, risk stratification, and therapy of pediatric acute leukemias: an update," Journal of Clinical Oncology, vol. 29, no. 5, pp. 551-565, 2011.

[3] S. P. Hunger, "Chromosomal translocations involving the E2A gene in acute lymphoblastic leukemia: clinical features and molecular pathogenesis," Blood, vol. 87, no. 4, pp. 1211-1224, 1996.

[4] S. P. Hunger, P. E. Devaraj, L. Foroni, L. M. Secker-Walker, and M. L. Cleary, "Two types of genomic rearrangements create alternative E2A-HLF fusion proteins in $\mathrm{t}(17 ; 19)$-ALL," Blood, vol. 83, no. 10, pp. 2970-2977, 1994.

[5] T. T. Inukai, K. Hirose, T. Inaba et al., "Hypercalcemia in childhood acute lymphoblastic leukemia: frequent implication of parathyroid hormone-related peptide and E2A-HLF from translocation 17;19," Leukemia, vol. 21, no. 2, pp. 288-296, 2007.

[6] J. Yeung, H. Kempski, M. Neat, S. Bailey, O. Smith, and H. J. M. Brady, "Characterization of the $t(17 ; 19)$ translocation by genespecific fluorescent in situ hybridization-based cytogenetics and detection of the E2A-HLF fusion transcript and protein in patients' cells," Haematologica, vol. 91, no. 3, pp. 422-424, 2006.

[7] L. Dahéron, F. Brizard, F. Millot et al., "E2A/HLF fusion gene in an acute lymphoblastic leukemia patient with disseminated intravascular coagulation and a normal karyotype," Hematology Journal, vol. 3, no. 3, pp. 153-156, 2002.

[8] P. E. Devaraj, L. Foroni, M. Sekhar et al., "E2A/HLF fusion cDNAs and the use of RT-PCR for the detection of minimal residual disease in $\mathrm{t}(17 ; 19)(\mathrm{q} 22 ; \mathrm{p} 13)$ acute lymphoblastic leukemia," Leukemia, vol. 8, no. 7, pp. 1131-1138, 1994.

[9] J. M. Glover, M. Loriaux, J. W. Tyner, B. J. Druker, and B. H. Chang, "In vitro sensitivity to dasatinib in lymphoblasts from a patient with $\mathrm{t}(17,19)(\mathrm{q} 22, \mathrm{p} 13)$ gene rearrangement pre-B acute lymphoblastic leukemia," Pediatric Blood \& Cancer, vol. 59, no. 3, pp. 576-579, 2012. 
[10] S. P. Hunger, K. Ohyashiki, K. Toyama, and M. L. Cleary, "Hlf, a novel hepatic bZIP protein, shows altered DNA-binding properties following fusion to E2A in $\mathrm{t}(17 ; 19)$ acute lymphoblastic leukemia," Genes and Development, vol. 6, no. 9, pp. 1608-1620, 1992.

[11] T. Matsunaga, T. Inaba, H. Matsui et al., "Regulation of annexin II by cytokine-initiated signaling pathways and E2AHLF oncoprotein," Blood, vol. 103, no. 8, pp. 3185-3191, 2004.

[12] K. Ohyashiki, H. Fujieda, J. Miyauchi et al., "Establishment of a novel heterotransplantable acute lymphoblastic leukemia cell line with a $t(17 ; 19)$ chromosomal translocation the growth of which is inhibited by interleukin-3," Leukemia, vol. 5, no. 4, pp. 322-331, 1991.

[13] S. C. Raimondi, E. Privitera, D. L. Williams et al., "New recurring chromosomal translocations in childhood acute lymphoblastic leukemia," Blood, vol. 77, no. 9, pp. 2016-2022, 1991.

[14] H. Shimonodan, J. Nagayama, Y. Nagatoshi et al., "Acute lymphocytic leukemia in adolescence with multiple osteolytic lesions and hypercalcemia mediated by lymphoblast-producing parathyroid hormone-related peptide: a case report and review of the literature," Pediatric Blood \& Cancer, vol. 45, no. 3, pp. 333-339, 2005. 


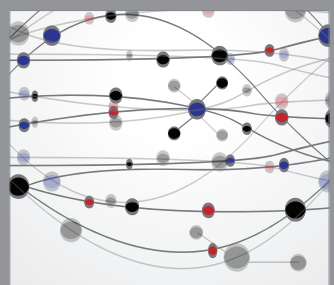

The Scientific World Journal
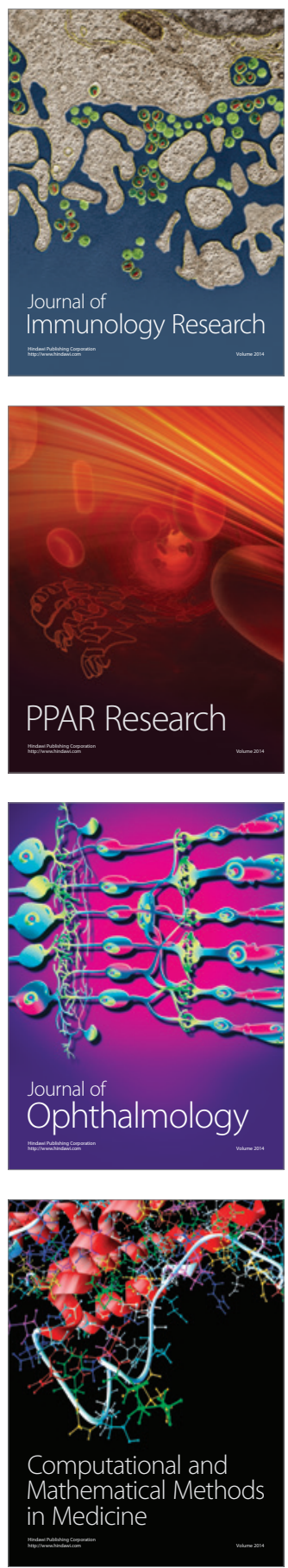

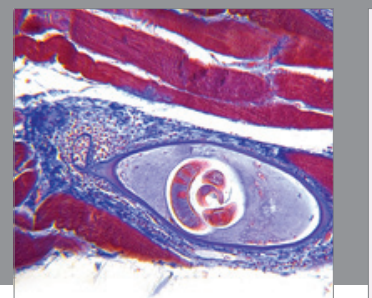

Gastroenterology

Research and Practice
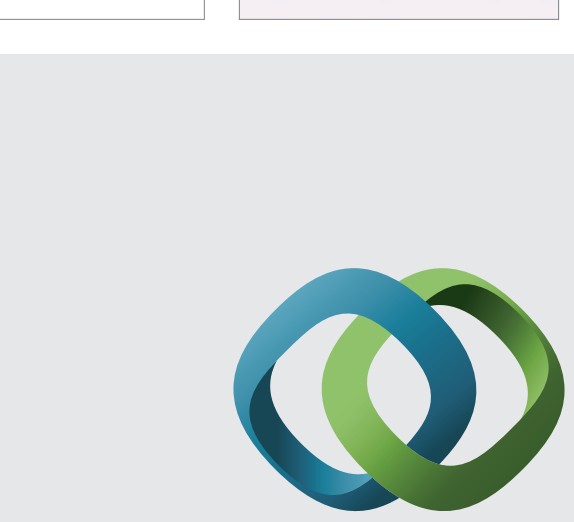

\section{Hindawi}

Submit your manuscripts at

http://www.hindawi.com
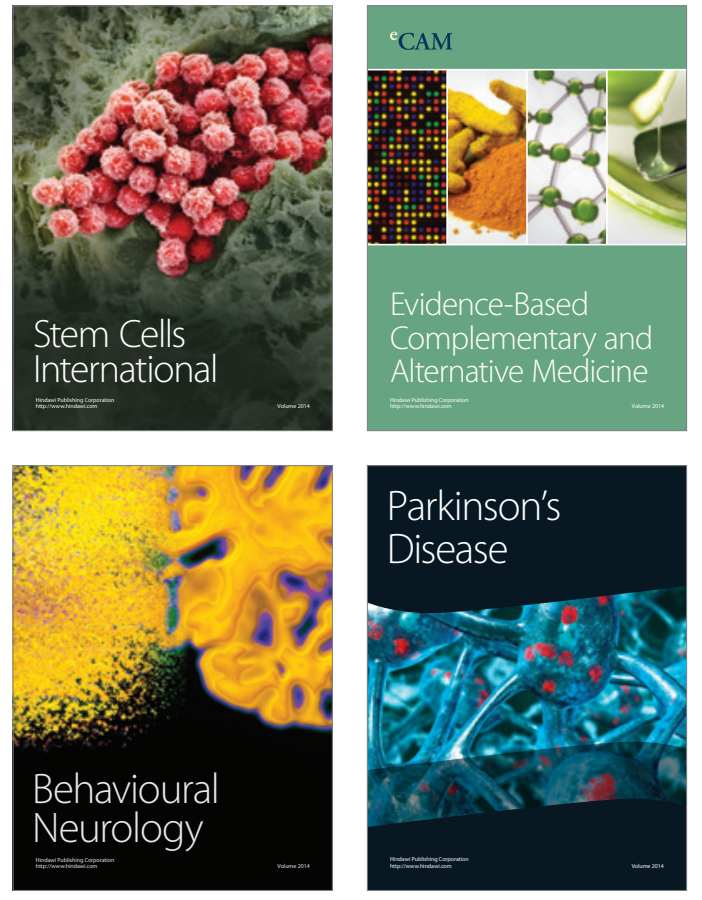
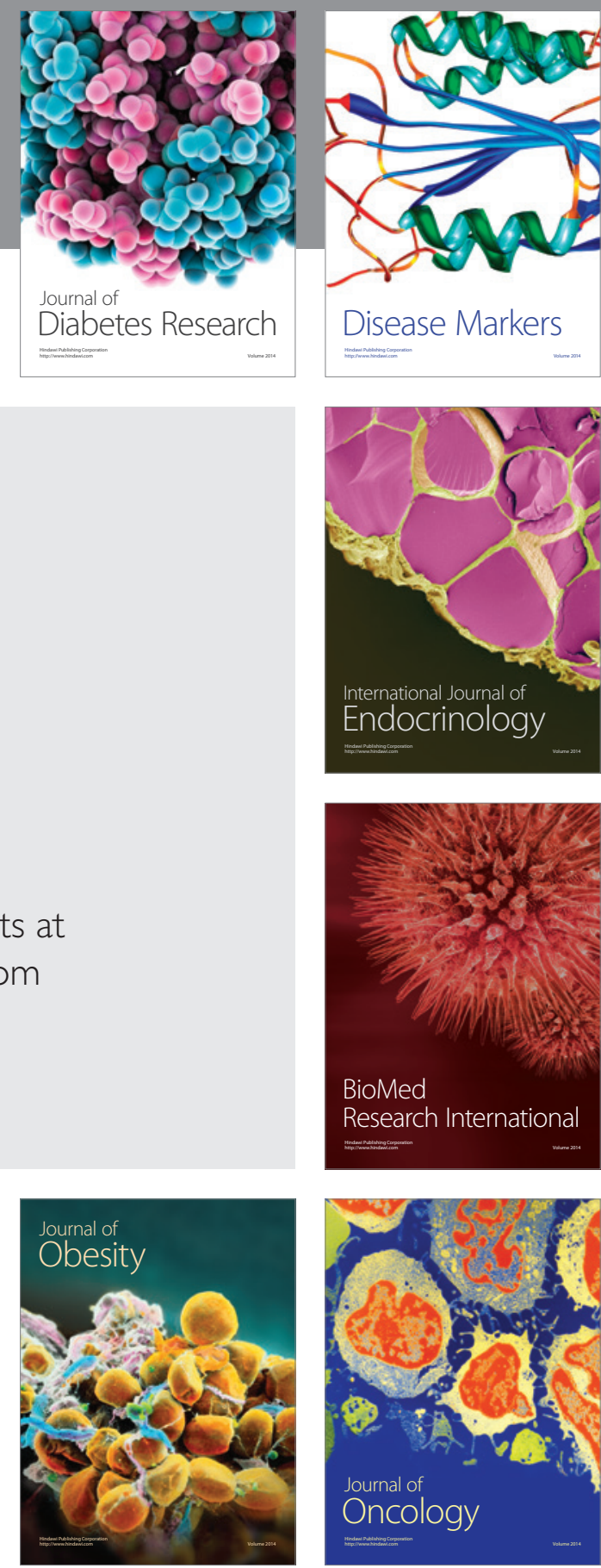

Disease Markers
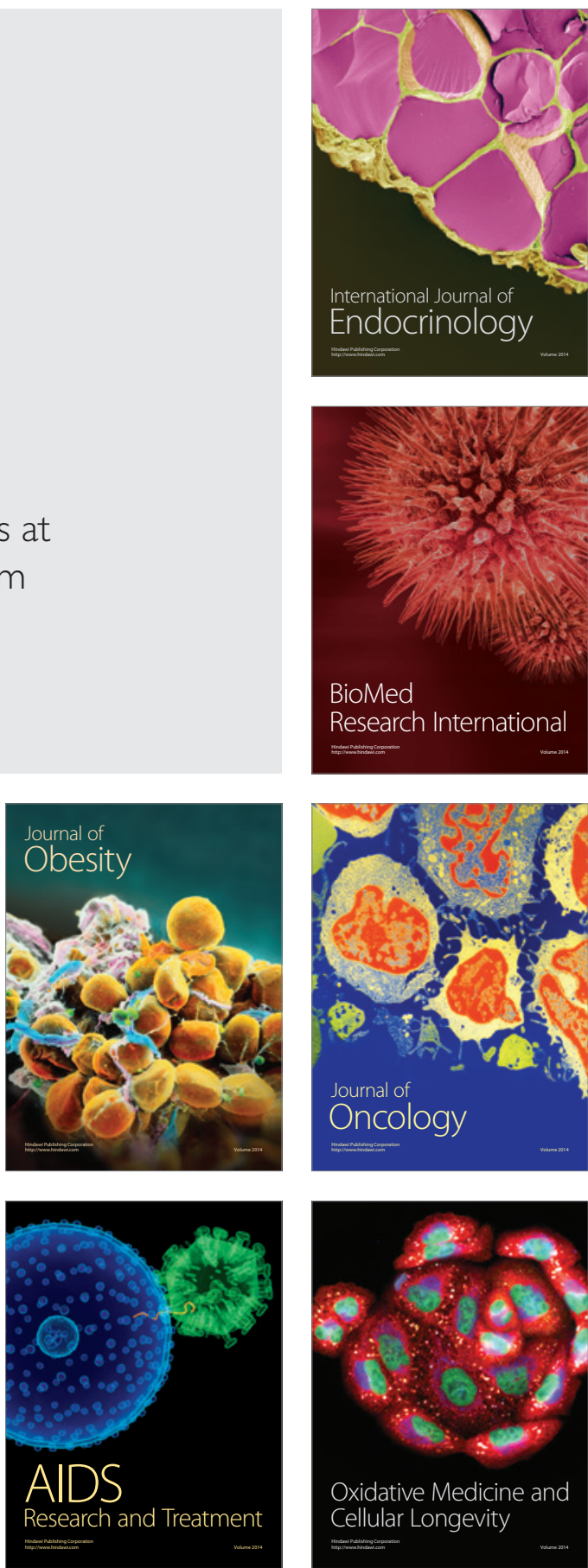